\title{
Quality Evaluation of Carabeef Patties Containing Different Levels of Water and Added Fat
}

\author{
A. Irshad ${ }^{1}$, S. Suresh kumar ${ }^{1}$, V. Chandirasekaran ${ }^{1}$, V. $\operatorname{Ramesh}^{2}$, \\ A. Natarajan ${ }^{3}$ and P. Sivakumar ${ }^{1}$ \\ ${ }^{1}$ Department of Livestock Products Technology (Meat Science), Veterinary College and \\ Research Institute, Namakkal - 637 002, India \\ ${ }^{2}$ Department of Livestock Production Management, Veterinary College and Research \\ Institute, Salem - 636 112, India \\ ${ }^{3}$ Department of Animal Feed Analytical and Quality Assurance Laboratory, Veterinary \\ College and Research Institute, Namakkal - 637 002, India \\ *Corresponding author
}

\section{A B S T R A C T}

Keywords

buffalo meat, patties, meat emulsion, vegetable oil and quality characteristics

Article Info

Accepted: 12 April 2021 Available Online: 10 May 2021
The objective of the present study was undertaken to standardize the optimum level of vegetable oil and added water in the development of carabeef patties. The lean meat was minced twice through $3 \mathrm{~mm}$ plate and prepared emulsion by using a bowl chopper. The patties were prepared with the incorporation of chilled water at 7,10 and $13 \%$ level and added vegetable fat at 10,12 and $14 \%$, respectively replacing the lean meat. The mean values of emulsion stability and cooking yield of carabeef patties was significantly $(\mathrm{P}<0.01)$ higher at $12 \%$ level of fat and $10 \%$ level of chilled water as compared to other treatment. A significant effect of different level of vegetable fat incorporation was observed with respect to sensory scores. The highest scores for appearance, juiciness, binding, texture and overall acceptability values noted for the products developed with $12 \%$ level of fat and $10 \%$ level of chilled water in the formulation. Thus, good quality carabeef patties could be prepared by incorporating $12 \%$ level of fat and 10 $\%$ level of chilled water in the formulation.

\section{Introduction}

Meat patties are ready to eat convenient emulsion-based meat products that are very famous throughout the world and widely used in breakfast. Usually, patties are consumed as in the form of burgers or along with other vegetable salads. The demand for low-fat meat 
products has greatly increased in recent years as high fat intake, especially saturated fats, is associated with an increased risk of chronic diseases of the circulatory system and some types of cancers (AHA, 1996). Since fat acts as a reservoir for flavour compounds and contributes to the product's texture, reducing the fat content in meat products may alter product quality.

Products with less fat than normal become firmer, more rubbery, less juicy, darker in colour, and more costly (Keeton, 1994; Desmond et al., 1998; Kirchner et al., 2000). The palatability of reduced-fat ground meat products, such as burgers and patties, can be increased by adding various fat substitutes. Among non-meat additives used as fat substitutes, fillers, binders, or extenders are wheat flour in chicken nuggets (Rao et al., 1997), soy- flour in buffalo meat burgers (Modi et al., 2003) etc.

The carabeef is very popular and widely favoured by consumers in most of the globe, including India. Unlike pork or beef, there is no religious taboo against carabeef. Carabeef is red meat that is often viewed as a potential competitor to beef and sheep meat. It is almost universally acceptable and free from culture, tradition, social and economic conditions (Verma et al., 2014 and Khandagale et al., 2013). Some peculiar qualities such as lower in calories, total fat, saturated fat and cholesterol make it suitable for healthconscious people. As buffaloes are slaughtered at a higher age, usually after their productive life, carabeef is less tender due to the presence of a higher amount of connective tissue (Lawrie, 1985). The amount of connective tissue in meat increases with the advancement of age (Kumar et al., 2012). The high amount of connective tissue in carabeef makes it tough and less juicy, and during post-mortem ageing, intramuscular connective tissue remains unchanged (Kannan et al., 2005), which could be overcome by suitable processing techniques (Hedrick et al., 1994).

Various researchers studied the quality characters of a considerable number of meat products, especially emulsion-based meat products from carabeef, including patties. However, the level of water and the added fat level used in the formulation also varying considerably from one another. Since the level of added fat and water level is very much related to the quality characteristics such as textural and sensory attributes of the products, the present study was envisaged to standardize the levels of vegetable fat and added water in the development of carabeef patties.

\section{Materials and Methods}

\section{Preparation of carabeef patties}

Buffalo meat, as boneless rounds, was obtained from the Meat Technology Unit, Mannuthy, Kerala Veterinary and Animal Sciences University, Thrissur. All subcutaneous and intermuscular fat was removed from the muscles. The experiment was conducted with three concentrations of fat $(10,12,14 \%$ final concentration) and three levels of chilled water $(7,10$ and $13 \%)$.

All other ingredient required for the experiment purchased from the local market. Carabeef was partially thawed overnight, cut into small cubes and double minced with meat mincer (MADO GmbH, NEW 713, Balmerstr10, Denmark). Meat emulsion was prepared in a bowl chopper (TC11 Bowl Cutter Scharfen, Germany). Pre-weighed quantity of minced carabeef, salt, sodium tripolyphosphate and sodium nitrite were added, and chopping was done for about 2-3 minutes. It was chopped again for 2 minutes after the addition of ice flakes. Refined vegetable oil was slowly incorporated while chopping till it was completely dispersed in the batter. Condiment 
paste, dry spice mix, refined wheat flour and other ingredients were added. Chopping was continued till uniform dispersion of all the ingredients and desired consistency of the emulsion was achieved. During chopping, the emulsion temperature was maintained at 10$12^{\circ} \mathrm{C}$ by the addition of slush ice.

\section{Formulation of carabeef patties}

Meat patties of about 70 gm each were formed manually utilizing patties mold of $80 \mathrm{~mm}$ diameter. Carabeef patties were cooked in a hot air oven at $180^{\circ} \mathrm{C}$ for $30 \mathrm{~min}$ within between turning of patties once. The core temperature of cooked patties was recorded using a probe thermometer (Digital Thermometer HI98501, Hanna Instruments, Inc.) that should reach to $72^{\circ} \mathrm{C}$.

\section{Analytical procedure}

\section{pH}

The $\mathrm{pH}$ of emulsion as well as carabeef patties was determined (Trout et al., 1992) by combination electrode digital $\mathrm{pH}$ meter (model CP 901, century Instrument Ltd. India), $10 \mathrm{gm}$ of sample was homogenized with the help of ultra turrax tissue homogenizer (T-25 Germany) for about a minute in $50 \mathrm{ml}$ of distilled water. The $\mathrm{pH}$ was recorded by immersing the electrode directly into the meat suspension.

\section{Emulsion stability}

The emulsion stability was determined as per the method of Townsend et al., (1968) with some modifications. About $25 \mathrm{gm}$ each of emulsion was placed in polyethylene bags and heated at $80^{\circ} \mathrm{C}$ in a thermostatically controlled water bath for 20 minutes. After cooling and draining the exudate, the cooked emulsion mass was weighed and yield was expressed as emulsion stability in percentage.

\section{Cooking yield}

Weights of raw and cooked carabeef patties were recorded. The percent cooking yield for each carabeef patties was calculated as follow.

Cooking yield (\%)

Wt. of cooked carabeef patties

Wt. of raw dough

\section{Shear force value $\left(\mathrm{Kg} / \mathrm{cm}^{2}\right)$}

Warner-Bratzler shear force (WBSF) of patties sample was determined by the method outlined by Wheeler et al., (1997). Each patties sample was cooked to an internal temperature of $80^{\circ} \mathrm{C}$ by monitored using a probe thermometer. It was measured as the force required for shearing $1 \mathrm{~cm}$ square block on a Texture Analyser (Model: TAXT Plus, Stable Microsystems) and expressed in $\mathrm{kg} / \mathrm{cm}^{2}$.

\section{Diameter and thickness reduction}

Raw and cooked carabeef patties diameter and thickness was measured by vernier calliper at three different points. Change in carabeef patties diameter and thickness was determined using the following equations:

Diameter reduction (\%)

$=($ Raw patties diameter - Cooked patties diameter $) \times 100$ Raw patties diameter

Thickness reduction (\%)

$=($ Raw patties thickness - Cooked patties thickness $) \times 100$ Raw patties thickness

\section{Sensory evaluation}

Samples from each formulation were randomly assigned for sensory evaluation. Patties were served warm to a six-membered 
trained panel (graduate students and staff of Department of Livestock Products Technology (Meat Science). The selection of panel members was based on their particular interests in taste and flavour acuity and ability to understand the test procedures. Panel members were trained in three 1-h sessions during which they were served patties from a wide variety of treatments to familiarize themselves with the properties to be evaluated. At each session, three patty samples were served immediately to panellists and were subjected to sensory evaluation for appearance, juiciness, flavour and texture. An eight-point scale was used where $8=$ extremely desirable, extremely juicy, intense in beef flavour, extremely tender and $1=$ denoted extremely undesirable, extremely dry, devoid of beef flavour and tough. For each replication of the experiment, five different sessions were conducted. Panellists evaluated a total of 10 patties for sensory analyses. Water and bread were served for cleaning the mouth between samples.

\section{Statistical analysis}

The trial was performed twice, and the data were evaluated by two-way analysis of variance (ANOVA). Duncans Multiple Test (Steel and Torrie, 1980) was used to determine the significant differences among means. The significance of differences was defined as $(\mathrm{P}<$ 0.05).

\section{Results and Discussion}

\section{Standardization of level of vegetable oil (fat)}

\section{Physico-chemical properties}

The mean values of various physic-chemical parameters carabeef patties containing vegetable fat (sunflower oil) at $10 \%, 12 \%$ and $14 \%$ levels are presented in Table 1 . The
Emulsion $\mathrm{pH}(\mathrm{EpH})$ of carabeef patties decreased significantly with an increased fat level, but comparable up to $12 \%$ level. This significant reduction $(\mathrm{P}<0.05)$ might be due to the decreased level of meat in the emulsion system. However, no significant change $(\mathrm{P}>0.05)$ in the product $\mathrm{pH}$ observed with all the three-level of vegetable fat in carabeef patties. Several researchers have found that the emulsion $\mathrm{pH}$ of meat batters increased with the addition of vegetable fat or soybean oil (Elgasim and Al-Wesali, 2000) or animal fat (Dzudie et al., 2002). Serdaroglu (2006) observed a non-significant change in the product $\mathrm{pH}$ of cooked beef patties with 5,10 or 20 per cent fat levels.

The mean and SE values of emulsion stability (ES) and cooking yield (CY) of carabeef patties was significantly $(\mathrm{P}<0.01)$ higher at 12 $\%$ level of fat as compared to 10 and $14 \%$ fat level. The values of ES and CY of patties with $14 \%$ fat level were the least value compared to 10 per cent. Cooking loss usually occurs during the cooking process because of the loss of moisture and fat, which resulted in the decrease of CY. Fat retention in meat and meat products is a complex phenomenon, and it is the total of several chemical and physical mechanisms. The swelling of the non-meat ingredient and some fat absorption by the fibre may interact with the protein of the ground meat matrix, thereby acting to prevent migration of fat from the product (Anderson and Berry, 2001). There was a possible connection between increasing cooking yield and higher fat retention. Anderson and Berry (2001) observed higher cooking yields and higher fat retention values in high-fat patties with pea fibre.

Serdaroglu (2006) also observed similar nonsignificant differences in cooking yields between the 5 and $10 \%$ fat levels in beef patties. But samples with $20 \%$ fat had lower cooking yields than patties with 5 and $10 \%$ 
fat. In contrast to our study results, Berry (1993) reported that cooking yields and emulsion stability were higher for patties manufactured with $4 \%$ rather than $20 \%$ fat. Cannel et al., (1989) reported no differences in cooking yield of patties between 5 and $20 \%$ fat levels. Keeping fat within the matrix of meat products during cooking and storage is necessary for ensuring sensory quality and acceptability (Anderson and Berry, 2001).

Kirchner et al., (2000) observed that more fat was lost at the $15 \%$ fat level than at the $5 \%$ fat level in beef patties.

The increase in patty thickness was significantly higher at 10 and 12 per cent fat level than 14 per cent. Reduction in patty diameter was highest at 14 per cent fat level compared to 10 and 12 per cent. The detrimental effect of dimensional change in the carabeef patties at 14 per cent level might be due to the reduced emulsion stability as well as the loss of fat from the emulsion system, which was evident from ES and CY of the product. The higher patty interior volume to external surface ratio in thick patty products probably contributed to their softness and improved juiciness. Similar trends due to enlarged patty size were also observed in $20 \%$ fat products by Cross and Berry (1980). They attributed these findings to larger size patties being better able to withstand the detrimental effects of cooking.

The mean and $\mathrm{SE}$ values shear force value $\left(\mathrm{Kg} / \mathrm{cm}^{2}\right)$ of carabeef patties reported a decreasing trend with increasing fat levels from $0.35 \pm 0.02$ to $0.29 \pm 0.02$. As protein has a more significant influence on binding and texture than fat, reduced-fat meat products can have a greater hardness (Jimenez-Colmenero et al., 1995). This relationship has been observed by other authors in various meat products (Akoh, 1998; Garcia et al., 2002; Serdarogulu and Sapanci-Ozsumer, 2003).

\section{Sensory attributes}

The mean values of various sensory attributes of carabeef patties containing different level of vegetable fat are presented in Table 2 and Fig 1. The scores of all the sensory attributes except saltiness of the product decreased significantly with increased vegetable oil/fat level from 12 per cent to 14 per cent. The scores of the carabeef patties prepared with 10 and 12 per cent fat level were comparable $(\mathrm{P}>0.05)$ among each other but slightly higher $(\mathrm{P}>0.05)$ than the product prepared with 10 per cent fat level. The decrease sensory scores of carabeef patties are the reflection of low emulsion stability, less binding, low shear force value, and reduced product yield resulted due to the release of fat and moisture.

Neither the fat level nor the cooking yield affected the saltiness scores of patties. Fat level influences the juiciness, flavour and texture scores. In contrast to our results, Serdaroglu (2006) observed samples formulated with $20 \%$ fat had higher scores for these parameters. Decreasing fat content in patties from 20 to $5 \%$ reduced juiciness, flavour and texture scores. Huffman and Egbert (1990) experienced no differences in beef flavour intensity over a range of 5-20\% fat content of patties. Other authors observed similar results in various meat products (Hung and Carpenter, 1997; Gujral et al., 2002 and Garcia et al., 2002).

\section{Standardization of level of chilled water/ice}

\section{Physico-chemical properties}

The mean values of various physic-chemical parameters carabeef patties containing chilled water at $7 \%, 10 \%$ and $13 \%$ levels are presented in Table 3. There was a nonsignificant increase in the mean and SE values of Emulsion $\mathrm{pH}(\mathrm{EpH})$ with an increased chilled water/ice level. 
Table.1 Formulation of carabeef patties

\begin{tabular}{|c|c|}
\hline Ingredients & Percentage $(\mathbf{w} / \mathbf{w})$ \\
\hline Carabeef & 65.00 \\
\hline Ice/Chilled water & $7 / 10 / 13$ \\
\hline Vegetable oil & $10 / 12 / 14$ \\
\hline Condiments & 5.00 \\
\hline Salt & 2.00 \\
\hline Refined wheat flour & 3.60 \\
\hline Dry spices & 1.80 \\
\hline STPP & 0.30 \\
\hline Sugar & 0.30 \\
\hline Nitrite & $100 \mathrm{ppm}$ \\
\hline
\end{tabular}

Table.2 Mean ( \pm ) SE ${ }^{\#}$ of physico-chemical properties of carabeef patties with three level of vegetable oil

\begin{tabular}{|c|c|c|c|c|}
\hline \multirow[t]{2}{*}{ Parameters } & \multicolumn{3}{|c|}{ Levels of fat (\%) } & \multirow[t]{2}{*}{ F Value } \\
\hline & 10 & 12 & 14 & \\
\hline Emulsion pH & $6.12 \pm 0.01^{b}$ & $6.10 \pm 0.01^{b}$ & $6.07 \pm 0.01^{\mathrm{a}}$ & $6.161 *$ \\
\hline Emulsion stability (\%) & $93.99 \pm 0.82^{b}$ & $96.93 \pm 0.71^{\mathrm{c}}$ & $89.91 \pm 0.99^{a}$ & $17.290 * *$ \\
\hline Cooking yield (\%) & $93.42 \pm 0.59^{b}$ & $95.22 \pm 0.47^{b}$ & $90.60 \pm 1.37^{\mathrm{a}}$ & $6.588 * *$ \\
\hline Product pH & $6.35 \pm 0.01$ & $6.36 \pm 0.02$ & $6.34 \pm 0.01$ & $0.752^{\mathrm{NS}}$ \\
\hline $\begin{array}{c}\text { Increase in patty } \\
\text { thickness }(\%)\end{array}$ & $56.85 \pm 4.72^{a b}$ & $64.77 \pm 4.47^{b}$ & $46.02 \pm 4.32^{\mathrm{a}}$ & $4.369 *$ \\
\hline $\begin{array}{l}\text { Reduction in patty } \\
\text { diameter }(\%)\end{array}$ & $14.74 \pm 1.09^{\mathrm{a}}$ & $15.06 \pm 0.50^{\mathrm{a}}$ & $17.89 \pm 1.12^{c}$ & $3.321 *$ \\
\hline $\begin{array}{l}\text { Shear force value } \\
\qquad\left(\mathrm{Kg} / \mathrm{cm}^{2}\right)\end{array}$ & $0.35 \pm 0.02^{c}$ & $0.33 \pm 0.06^{\mathrm{b}}$ & $0.29 \pm 0.02^{\mathrm{a}}$ & $28.808 * *$ \\
\hline
\end{tabular}

${ }^{\#}$ Means bearing different superscripts between columns differ significantly.

$\mathrm{n}_{1}($ Physico-chemical parameter $)=6, \mathrm{n}_{2}$ (Dimensional parameters $)=18, \mathrm{n}_{3}$ (Shear force value $)=30$ for each treatment.

* - Significant $(P \leq 0.05)$;** Highly significant $(P \leq 0.01) ; N S$ - Non Significant

Table.3 Mean $( \pm) \mathrm{SE}^{\#}$ of Sensory attributes of carabeef patties with three level of vegetable oil

\begin{tabular}{|c|c|c|c|c|}
\hline \multirow{2}{*}{ Attributes } & \multicolumn{3}{|c|}{ Levels of fat (\%) } & \multirow{2}{*}{ F Value } \\
\cline { 2 - 5 } & $\mathbf{1 0}$ & $\mathbf{1 2}$ & $\mathbf{1 4}$ & \\
\hline General appearance & $6.81 \pm 0.13^{\mathrm{ab}}$ & $6.99 \pm 0.09^{\mathrm{b}}$ & $6.55 \pm 0.13^{\mathrm{a}}$ & $3.436^{*}$ \\
\hline Flavour & $7.07 \pm 0.14^{\mathrm{b}}$ & $7.18 \pm 0.16^{\mathrm{b}}$ & $6.54 \pm 0.12^{\mathrm{a}}$ & $5.580^{* *}$ \\
\hline Juiciness & $7.05 \pm 0.18^{\mathrm{b}}$ & $7.45 \pm 0.15^{\mathrm{b}}$ & $6.49 \pm 0.24^{\mathrm{a}}$ & $6.427^{* *}$ \\
\hline Binding & $6.73 \pm 0.12^{\mathrm{ab}}$ & $7.00 \pm 0.15^{\mathrm{b}}$ & $6.29 \pm 0.21^{\mathrm{a}}$ & $4.845^{*}$ \\
\hline Texture & $6.76 \pm 0.09^{\mathrm{b}}$ & $7.09 \pm 0.13^{\mathrm{b}}$ & $6.17 \pm 0.17^{\mathrm{a}}$ & $11.973^{* *}$ \\
\hline Saltiness & $6.88 \pm 0.16$ & $6.81 \pm 0.06$ & $6.80 \pm 0.13$ & $0.073^{\text {NS }}$ \\
\hline Overall acceptability & $6.92 \pm 0.09^{\mathrm{b}}$ & $7.02 \pm 0.14^{\mathrm{b}}$ & $6.26 \pm 0.17^{\mathrm{a}}$ & $8.417^{* *}$ \\
\hline
\end{tabular}

"Means bearing different superscripts between columns differ significantly. $\mathrm{n}=21$ for each treatment.

* - Significant $(P \leq 0.05)$; ** Highly significant $(P \leq 0.01)$; NS - Non Significant 
Table.4 Mean $( \pm) \mathrm{SE}^{\#}$ of physico-chemical properties of carabeef patties with three level of ice/chilled water

\begin{tabular}{|c|c|c|c|c|}
\hline \multirow{2}{*}{ Parameters } & \multicolumn{3}{|c|}{ Levels of ice/chilled water (\%) } & \multirow{2}{*}{ F Value } \\
\cline { 2 - 5 } & $\mathbf{7}$ & $\mathbf{1 0}$ & $\mathbf{1 3}$ & \\
\hline Emulsion pH & $6.09 \pm 0.01$ & $6.09 \pm 0.01$ & $6.11 \pm 0.01$ & $2.508^{\mathrm{NS}}$ \\
\hline Emulsion stability (\%) & $96.55 \pm 0.88$ & $97.75 \pm 0.62$ & $96.74 \pm 0.56$ & $0.840^{\mathrm{NS}}$ \\
\hline Cooking yield (\%) & $95.68 \pm 1.05$ & $97.47 \pm 0.42$ & $95.54 \pm 0.44$ & $0.130^{\mathrm{NS}}$ \\
\hline Product pH & $6.29 \pm 0.01^{\mathrm{a}}$ & $6.32 \pm 0.01^{\mathrm{ab}}$ & $6.33 \pm 0.01^{\mathrm{b}}$ & $5.000^{*}$ \\
\hline Increase in patty thickness (\%) & $59.64 \pm 1.57^{\mathrm{b}}$ & $57.84 \pm 1.83^{\mathrm{b}}$ & $53.00 \pm 1.26^{\mathrm{a}}$ & $4.790^{*}$ \\
\hline Reduction in patty diameter (\%) & $14.41 \pm 0.57^{\mathrm{b}}$ & $13.64 \pm 0.66^{\mathrm{b}}$ & $10.66 \pm 0.49^{\mathrm{a}}$ & $11.820^{*}$ \\
\hline Shear force value $\left(\mathbf{K g} / \mathbf{c m}^{\mathbf{2}}\right)$ & $0.36 \pm 0.01^{\mathrm{b}}$ & $0.37 \pm 0.00^{\mathrm{b}}$ & $0.35 \pm 0.02^{\mathrm{a}}$ & $4.520^{*}$ \\
\hline
\end{tabular}

${ }^{\#}$ Means bearing different superscripts between columns differ significantly.

$\mathrm{n}_{1}$ (Physico-chemical parameter) $=6, \mathrm{n}_{2}$ (Dimensional parameters) $=18, \mathrm{n}_{3}$ (Shear force value $)=30$ for each treatment. * $\quad$ Significant $(P \leq 0.05) ; * * \quad$ Highly significant $(P \leq 0.01) ; N S-$ Non Significant

Fig.1 Flow diagram for preparation of carabeef patties

Frozen buffalo meat at $-18 \pm 1^{\circ} \mathrm{C}$

Thawing of buffalo meat at $4 \pm 1^{\circ} \mathrm{C}$ for $24 \mathrm{hrs}$

Mincing through $8 \mathrm{~mm}$ sieve plate

Chopping in bowl chopper with salt, STPP and sodium nitrite

with ice flakes

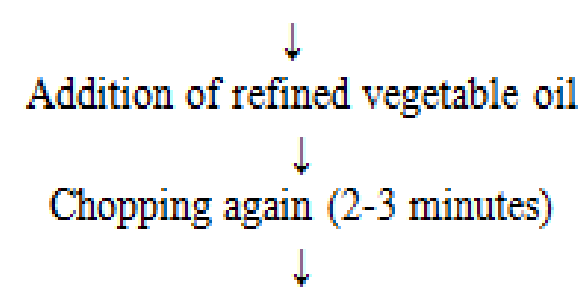

Addition of spices, condiments and other ingredients

Chopping till uniform dough formation

Preparation of patties each of about $70 \mathrm{gm}$ utilizing patties mold of $80 \mathrm{~mm}$ diameter

Cooking in hot air oven at $180^{\circ} \mathrm{C}$ for 30 minutes with turning once

Cooling, packaging and storage of carabeef patties at $4 \pm 1^{\circ} \mathrm{C}$

Sensory evaluation and sample analysis 
Table.5 Mean $( \pm)$ SE* of Sensory attributes of carabeef patties with three level of ice/chilled water

\begin{tabular}{|c|c|c|c|c|}
\hline \multirow{2}{*}{ Attributes } & \multicolumn{3}{|c|}{ Levels of fat (\%) } & \multirow{2}{*}{ F Value } \\
\cline { 2 - 5 } & $\mathbf{7}$ & $\mathbf{1 0}$ & $\mathbf{1 3}$ & \\
\hline General appearance & $7.05 \pm 0.48$ & $7.17 \pm 0.08$ & $7.11 \pm 0.66$ & 1.000 \\
\hline Flavour & $7.09 \pm 0.04$ & $7.11 \pm 0.08$ & $7.13 \pm 0.08$ & 0.063 \\
\hline Juiciness & $7.13 \pm 0.11$ & $7.24 \pm 0.14$ & $7.14 \pm 0.09$ & 0.274 \\
\hline Binding & $7.05 \pm 0.08$ & $7.19 \pm 0.09$ & $7.06 \pm 0.10$ & 0.724 \\
\hline Texture & $7.02 \pm 0.09$ & $7.24 \pm 0.10$ & $7.12 \pm 0.08$ & 1.320 \\
\hline Saltiness & $7.19 \pm 0.08$ & $7.14 \pm 0.06$ & $7.02 \pm 0.10$ & 1.086 \\
\hline Overall acceptability & $7.08 \pm 0.07$ & $7.14 \pm 0.09$ & $7.10 \pm 0.08$ & 0.144 \\
\hline
\end{tabular}

*Means bearing different superscripts between columns differ significantly.

$\mathrm{n}=21$ for each treatment.

Fig.2 Sensory attributes of carabeef patties with three level of vegetable oil

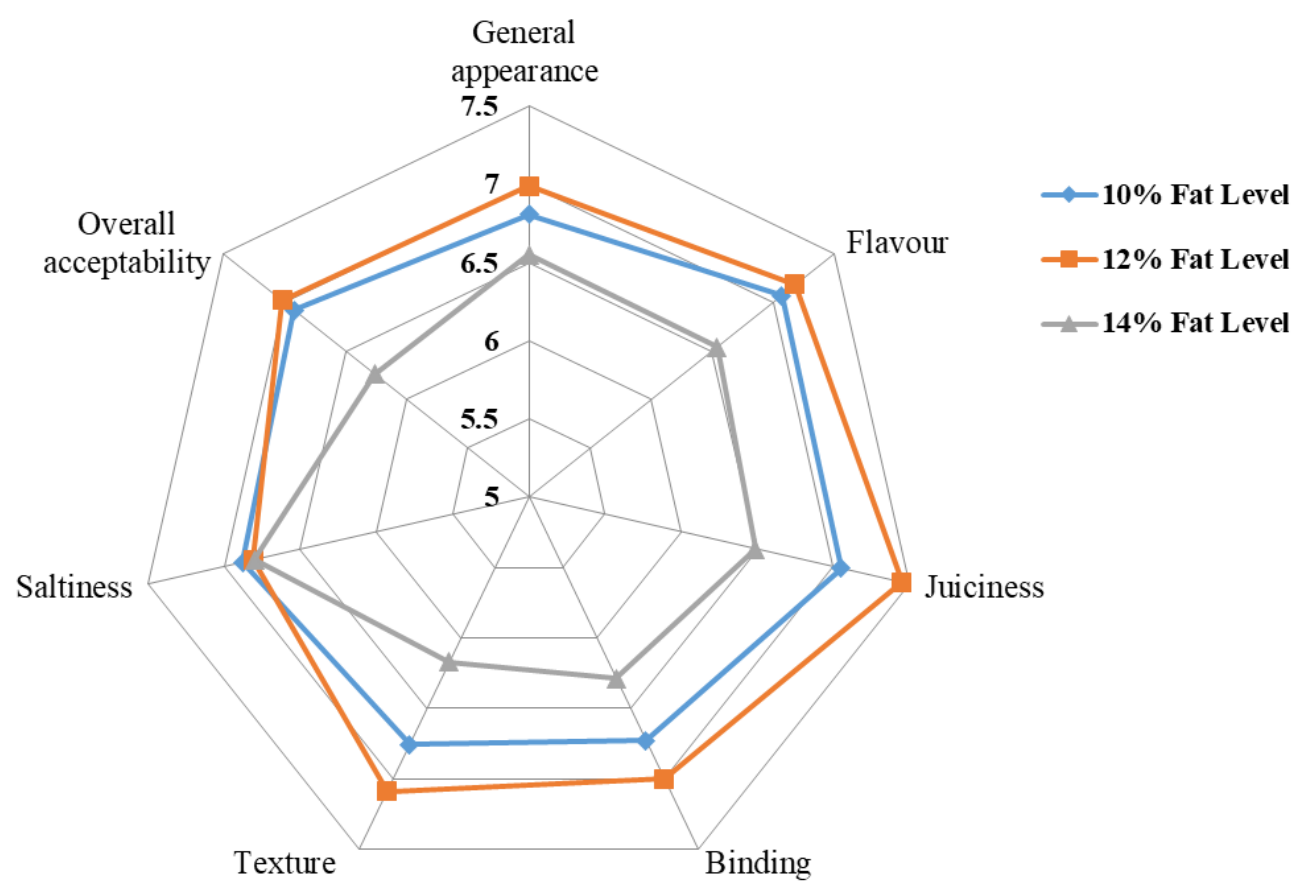

This could be due to the near-neutral $\mathrm{pH}$ of the chilled water or ice. However, the mean and $\mathrm{SE}$ value of product $\mathrm{pH}(\mathrm{PpH})$ was increased significantly $(\mathrm{P}<0.05)$ from $6.29 \pm 0.01$ to $6.33 \pm 0.01$ with the increase of chilled water/ice level. The apparent reason for this is the addition of ice by replacing lean meat. A similar kind of results was observed by Singh et al., (2014) in the raw chevon cutlets. They observed the $\mathrm{pH}$ value of raw cutlet increased significantly $(\mathrm{p}<0.05)$ for treatment with 3 per cent ice level than the control (without ice), however, the $\mathrm{pH}$ of raw treatments were comparables. The $\mathrm{pH}$ of the cooked products increased significantly $(\mathrm{p}<0.05)$ in treatment I ( $3 \%$ added ice) than the $\mathrm{pH}$ of control. The $\mathrm{pH}$ of the cooked treatment II (6\% added ice) was comparable to the treatment I and III (9\% 
added ice). However, it was significantly $(p<0.5)$ higher for treatment III than the control and treatment I.

The mean values of ES and CY of carabeef patties with different levels of ice/chilled water were comparable to each other statistically. Still, there is a non-significant increase in the value at the 10 per cent level. However, there was no significant difference between the 7 and 13 per cent level, probably due to an adequate amount of water available at 10 per cent level addition in the formulation. The non-significant increase in cooking yield at 10 per cent level might be due to increased protein-water interaction at an adequate level leading to better water holding capacity and consequently improved binding. This agrees with the results of Kumar (2002), who used $10 \mathrm{ml}$ of added water in association with different salts to prepare restructured buffalo meat blocks. Singh et al., (2014) also observed similar kinds of result in the raw chevon cutlets with different water levels. The CY was significantly $(p<0.5)$ decreased in treatment $\mathrm{I}$, which in turn showed significantly $(\mathrm{p}<0.5)$ lower $\mathrm{CY}$ than treatment II.

Per cent increase in patty thickness was significantly reduced $(\mathrm{P}<0.05)$ at 13 per cent water/ice level than patties with 7 and 10 per cent water or ice. A similar trend observed in the reduction in patty diameter with the least significant $(\mathrm{P}<0.05)$ value $(10.66 \pm 0.49)$ at 13 per cent level of water or ice compared with 7 and 10 per cent level. This might be due to the better ES and CY associated with the respective level of water or ice inclusion. The mean values shear force value $\left(\mathrm{Kg} / \mathrm{cm}^{2}\right)$ of carabeef patties decreased significantly with increased water or ice level. This results in agreement with the studies conducted by Cross and Berry (1980). The adverse effects of cooking patties with a higher level of water addition are directly associated with emulsion stability, texture and binding properties, water holding capacity and fat, and moisture loss (Gujral et al., 2002).

\section{Sensory attributes}

The mean values of various sensory attributes of carabeef patties containing chilled water at $7 \%, 10 \%$ and $13 \%$ levels are presented in Table 4 . The mean values of all the sensory attributes of the carabeef patties were comparable to each other. However, the sensory scores of the patties with 10 per cent chilled water or ice level showed a nonsignificant higher value than other samples. This might be due to the release of fat and moisture from the product due to limited binding sites available in the meat proteins for water. This is in agreement with Kumar and Sharma (2007) in restructured carabeef meat blocks and Moiseev and Cornforth (1997) in emulsion-based beef rolls.

Therefore, it was concluded that during the preparation of carabeef patties, $12 \%$ level of added vegetable fat and $10 \%$ level of chilled water/ice by replacing the lean meat was considered optimum for preparation of the good quality of carabeef patties.

\section{Acknowledgement}

The authors gratefully acknowledge the Tamil Nadu Veterinary and Animal Sciences University for the financial supports and facility provided to research as part of the $\mathrm{PhD}$ programme.

\section{References}

AHA, 1996. Dietary guidelines for healthy Americans. Circulation, 94: 17951800

Akoh, C. C. 1998. Fat replacers. Food Technology, 52: 47- 53.

Anderson, E. T. and Berry, B. W. 2001. 
Effects on inner pea fiber on fat retention and cooking yield in high fat ground beef. Food Research International, 34: 689-694.

Berry, B. W. J. 1993. Fat level and freezing temperature affect sensory, shear, cooking and compositional properties of ground beef. Journal of Food Science, 58: 34-37, 48.

Cannel, L. E., Savell, J. W., Smith, S. B., Cross, H. R. and St. John, L. C. 1989. Fatty acid composition and caloric value of ground beef containing low levels of fat. Journal of Food Science, 54: 1163-1168.

Cross, H. R. and Berry, B. W. 1980. Factors affecting palatability and cooking properties of ground beef pattiesfrozen lean, patty size, and surface treatment. J. Food Sci. 45:1463-1465.

Desmond, E. M., Trou, D. J. and Buckley, D. J. 1998. The effects of tapioca starch, oat fibre and whey protein on the physical and sensory properties of lowfat beef burgers. LWT- Food Sci. Tech. 31: 653-657.

Dzudie, T., Scher, J. and Hardy, J. 2002. Common bean flour as an extender in beef sausages. Journal of Food Engineering, 52: 143-147.

Elgasim, E. A. and Al-Wesali, M. S. 2000. Water activity and hunter colour values of beef patties extended with samh (mesembryanthemum forsskalei hochst) flour. Food Chemistry, 69: 181-185.

Garcia, M. L., Dominguez, R., Galvez, M. D., Casas, C. and Selgas, M. D. 2002. Utilization of cereal and fruit fibres in low fat dry fermented sausages. Meat Sci. 60: 227-236.

Gujral, H. S., Kaur, A., Singh, N. and Sodhi, S.N. 2002. Effect of liquid egg, fat and textured soy protein and cooking properties of raw and baked patties from goat meat. Journal of Food
Engineering, 53: 377-385.

Hedrick, H. B., Aberle, E. D, Forrest, J. C., Judge, M. D. and Merkel, R. A. 1994. In: Principles of meat science (pp. 144-150). Iowa: Kendall/ Hunt Publishing Co.

Huffman, D. L. and Egbert, W. R. 1990. Advances in Lean Ground Beef Production. Alabama Agriculture Experimental Station Bulletin 606, Auburn University, Montgomery, AL.

Hung, C.L and Carpenter, J. A. 1997. Optimizing quality of frankfurters containing oat bran and added water. Journal of Food Science, 62:194-197.

Kannan, G., Gadiyaram, K. M., Galipalli, S., Carmichael, A., Kouakou, B., Pringle, T. D., Mcmillin, K. W. and Gelaye, S.W. 2005. Meat quality in goats as influenced by dietary protein and energy levels, and post-mortem aging. Small Rum. Res., 61(1), 45-52

Keeton, J. T. 1994. Low-fat meat products, technological problems with processing. Meat Science, 36: 261276.

Khandagale, R. M., Keshri, R. C., Kumar, P. and Singh, P. K. 2013. Microbial quality of pork nuggets incorporated with fish flesh under refrigeration. J. An. Res., 3(1):37-41.

Kirchner, M. J., Beasleyi, L. C., Harris, K. B. and Savell, J. W. 2000. Evaluating the cooking and chemical characteristics of low-fat ground beef patties. Journal of Food Composition and Analysis, 13: 253-254.

Kumar, P., Kumar, S. and Bhat, Z. F. 2012. Effect of sex on the quality characteristics of nuggets prepared from spent Vanaraja chicken meat. Ind. J. Poult Sci., 47(2):218-221.

Kumar, R. R. and Sharma, B. D. 2006. Efficacy of barley flour as extender in chicken patties from spent hen meat. J. Appl. Anim. Res. 30: 53-55. 
Kumar, S. 2002. Effect of milk proteins on the quality of restructured buffalo meat blocks. Thesis, M.V.Sc. Deemed University, Indian Veterinary Research Institute, Izatnagar, India.

Lawrie, R. A. 1985. Meat sci., (pp. 112-146) (4th ed.). Oxford: Pergamon Press.

Modi, V. K., Mahendrakar, N. S., Rao, D. N. and Sachindra, N. M. 2003. Quality of buffalo meat burger containing legume flours as binders. Meat Science, 66: 143-149.

Moiseev, I. V., and Cornforth, D. P. 1997. Sodium hydroxide and sodium tripolyphosphate effects on bind strength and sensory characteristics of restructured beef rolls. Meat Science, 45: 53-60.

Rao, K. H., Singh, R. R. B., Anjaneyulu, A. S. R., Rao, K. V. S. S. and Yadav, P. L. 1997. Effects of caseinase and refined wheat flour on the quality of chicken nuggets from spent hens. Indian Journal of Animal Science, 67: 10041006.

Serdaroglu, M. 2006. The characteristics of beef patties containing different levels of fat and oat flour. International Journal of Food Science and Technology, 41(2):147-153. doi:10.1111/j.1365-2621.2005.01041.x

Serdaroglu, M. and Sapanciozsumer, M. 2003. Effects of soy protein, whey powder and wheat gluten on quality characteristics of cooked beef sausages formulated with 5, 10 and $20 \%$ fat. Electronic Journal of Polish Agricultural Universities. Series: Food
Science and Technology, 6: 1-9.

Singh, P. K., Sunil Kumar, Pavan Kumar and Z. F. Bhat, 2014. Standardization of Shredded Potato and Added Water Levels in the Development of Chevon Cutlets Journal of Animal Research: v.4 n.2, p. 251-261. Dec. 2014 DOI Number: $10.5958 / 2277$ 940X.2014.00012.6

Steel, R. G. D. and Torrie, J. H. 1980. The Principles and Procedures of Statistics, $2^{\text {nd }}$ Edn. New York: McGrawHill.

Townsend, W. E., Witnauer, L. P., Riloff, J. A. and Swift, C.E. 1968. Comminuted meat emulsions. Differential thermal analysis of fat transition. Food Technol., 22: 319-323.

Trout, E. S., Hunt, M. C., Johnson, D. E., Claus, J. R., Kastner, C. L. and Kropt, D. H. 1992. Characterstics of low fat ground beef containing texture modifying ingredients. J. Food Sci. 57: 19-24.

Verma, A. K., Singh, V. P. and Pathak, V. 2014. Effect of jackfruit supplement and ageing on the Physico-chemical, texture and sensory characteristics of Chevon patties. J. Appl Ani Res., doi.org/10.1080/09712119.2014.96309 4

Wheeler, T. L., S. D. Shackelford, L. P. Johnson, M. F. Miller, R. K. Miller, and M. Koohmaraie. 1997. A comparison of WarnerBratzler shear force assessment within and among institutions. J. Anim. Sci. 75:24232432.

\section{How to cite this article:}

Irshad, A., S. Suresh kumar, V. Chandirasekaran, V. Ramesh, A. Natarajan and Sivakumar, P. 2021. Quality Evaluation of Carabeef Patties Containing Different Levels of Water and Added Fat. Int.J.Curr.Microbiol.App.Sci. 10(05): 32-42. doi: https://doi.org/10.20546/ijcmas.2021.1005.007 